\title{
New Vertebrate Fossil Site from the Early Cretaceous Sao Khua Formation, Sakon Nakhon Province, Northeastern Thailand
}

\author{
Phornphen Chanthasit ${ }^{1 *}$, Suravech Suteethorn ${ }^{2,3}$, Wilailuck Naksri ${ }^{4}$, Haiyan Tong ${ }^{2}$, \\ Kamonlak Wongko ${ }^{5}$, Teppei Sonoda ${ }^{6}$
}

\author{
${ }^{1}$ Sirindhorn Museum, Department of Mineral Resources, Sahatsakhan, Kalasin, Thailand \\ ${ }^{2}$ Palaeontological Research and Education Centre, Mahasarakham University, Kantarawichai, Mahasarakham, Thailand \\ ${ }^{3}$ Department of Biology, Faculty of Science, Mahasarakham University, Mahasarakham, Thailand \\ ${ }^{4}$ Northeastern Research Institute of Petrified Wood and Mineral Resources, Nakhon Ratchasima Rajabhat University, Nakhon \\ Ratchasima, Thailand \\ ${ }^{5} \mathrm{Phu}$ Wiang Fossil Research Center and Dinosaur Museum, Department of Mineral Resources, Khon Kaen, Thailand \\ ${ }^{6}$ Fukui Prefectural Dinosaur Museum, Fukui, Japan \\ Email:*aom025@gmail.com
}

How to cite this paper: Chanthasit, $\mathrm{P}$., $\mathrm{Su}-$ teethorn, S., Naksri, W., Tong, H.Y., Wongko, K. and Sonoda, T. (2019) New Vertebrate Fossil Site from the Early Cretaceous Sao Khua Formation, Sakon Nakhon Province, Northeastern Thailand. Open Journal of Geology, 9, 619-622.

https://doi.org/10.4236/ojg.2019.910057

Received: August 16, 2019

Accepted: September 21, 2019

Published: September 24, 2019

Copyright (c) 2019 by author(s) and Scientific Research Publishing Inc. This work is licensed under the Creative Commons Attribution International License (CC BY 4.0).

http://creativecommons.org/licenses/by/4.0/

\begin{abstract}
A new vertebrate fossil site, "Phu Sung" in Sakon Nakhon Province was discovered. Various vertebrate fossils belonging to fresh water shark, bony fish, turtle, crocodile and dinosaur were found in reddish silty mudstone of the Early Cretaceous Sao Khua Formation of the Khorat Group. Crocodilian remains including a complete skull and partial articulated skeleton are very well preserved associated with turtle remains. Moreover, well preserved 19 turtle shells were found accumulated together. These discoveries will certainly fulfill our knowledge about these aquatic taxa from the Early Cretaceous Sao Khua Formation. The exceptional preservation of Phu Sung fossils could probably relate to the paleoenvironment in the Early Cretaceous of Thailand.
\end{abstract}

\section{Keywords}

Vertebrate, Sao Khua Formation, Early Cretaceous, Northeastern Thailand

\section{Introduction}

The Lower Cretaceous Sao Khua Formation of the Khorat Group mainly distributed in northeastern Thailand (Figure 1), is well known for the rich fossils especially for dinosaurs. Some Sao Khua fossil sites in Sakon Nakon were previously mentioned about the discoveries of vertebrate remains including fresh 


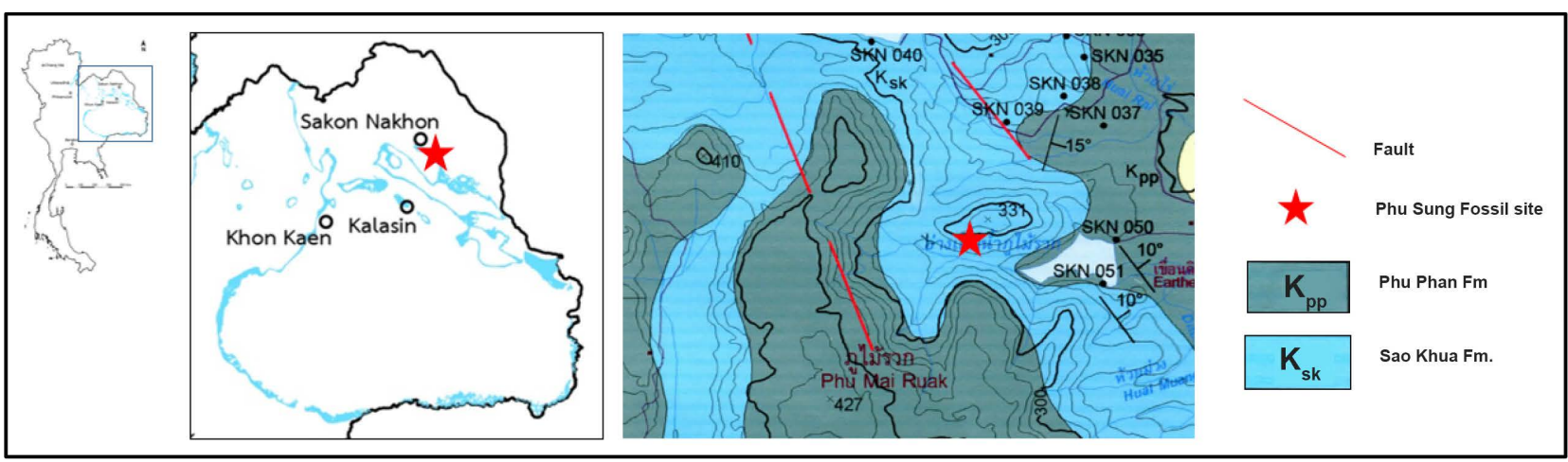

Figure 1. Distribution of Sao Khua Formation and Phu Sung locality showing in red star.

water shark, bony fish, turtles, crocodiles, pterosaurs, dinosaurs and lizard eggs, however, most of them are fragmentary and rarely articulated. One interesting site of Sakon Nakhon, Phu Din Daeng, found in 2012 has been reported with a new adocid turtle [1]. Most recently, a new vertebrate fossil site "Phu Sung" was firstly found by a forest ranger in the National Reserved Forest of Phu Lom Khao and Phu Peg area. Several vertebrate fragments, such as dinosaur, crocodile and turtle were found on the surface obviously in the intermittent rills. In December 2018, the excavation was proceeded and found the exceptionally preserved articulated crocodile and turtles remains which kind of preservation has rarely reported from the Lower Cretaceous of Thailand.

\section{Geological Setting}

Phu Sung is located at the eastern side of Phu Phan Range in Muang Sakon Nakhon District, Sakon Nakhon Province (Figure 1). Fossils found in situ from reddish silty mudstone which is underlain and overlain by sandstone beds. The site is mapped in the Barremian Sao Khua Formation of the Khorat Group [2].

\section{Fossil Assemblage}

Phu Sung fossil site yields various vertebrate taxa. Many remains were collected from the erosional surface including a tooth of Chondrichthyes possibly belonging to Heteroptychodus sp., a maxilla of a bony fish sinamiid possibly Siamamia and dinosaurs. The dinosaur material consists of a large isolated tooth with serration and manual claws of indeterminate theropods, a conical tooth fragment of a spinosaurid, a peg-like tooth of a sauropod similar to one of Phuwiangosaurus sirindhornae and large bone fragments of indeterminate taxon. Surprisingly in the mudstone layer, crocodilian remains including a complete skull and partial articulated skeleton are found associated with turtle shell and bones (Figure 2). This crocodile skull is the most complete skull ever found from the Sao Khua Formation. It is probably referred to a goniopholidid and interesting to compare with Siamosuchus phuphokensis which found from another Early Cretaceous site of Sakon Nakhon Province [3] and Goniopholis phuwiangensis from Phuwiang, Khon Kaen Province [4]. These two Thai goniopholidid 


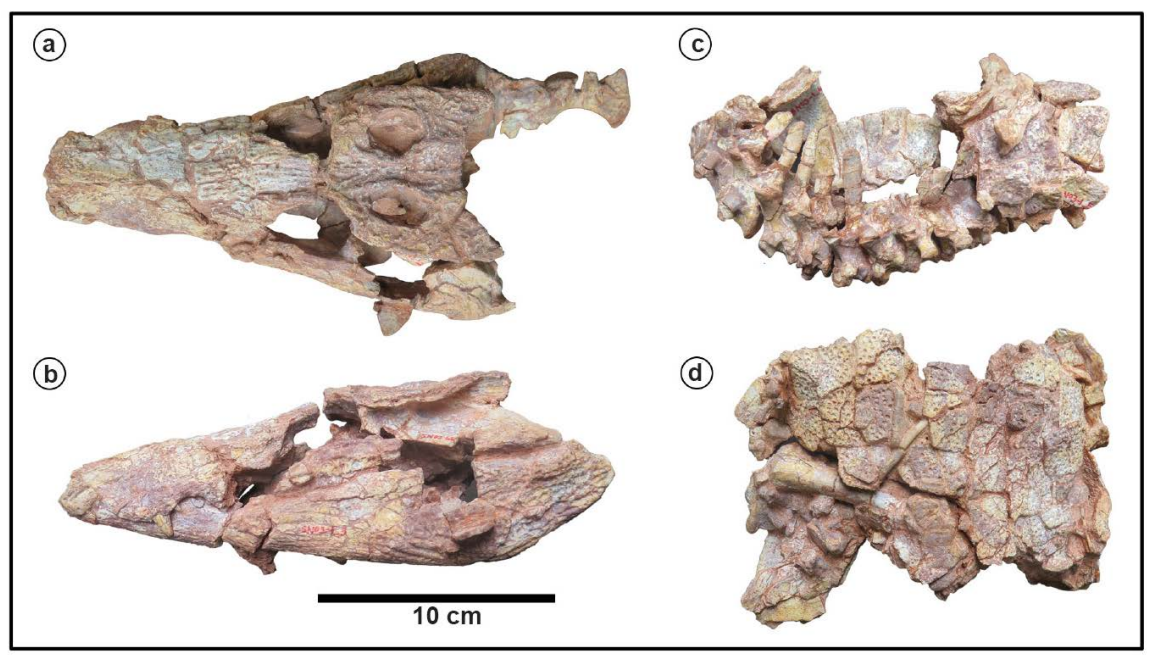

Figure 2. Crocodilian remains including a nearly complete skull (a) in dorsal and (b) in left lateral views, (c) partial articulated vertebrae and (d) articulated osteoderms.

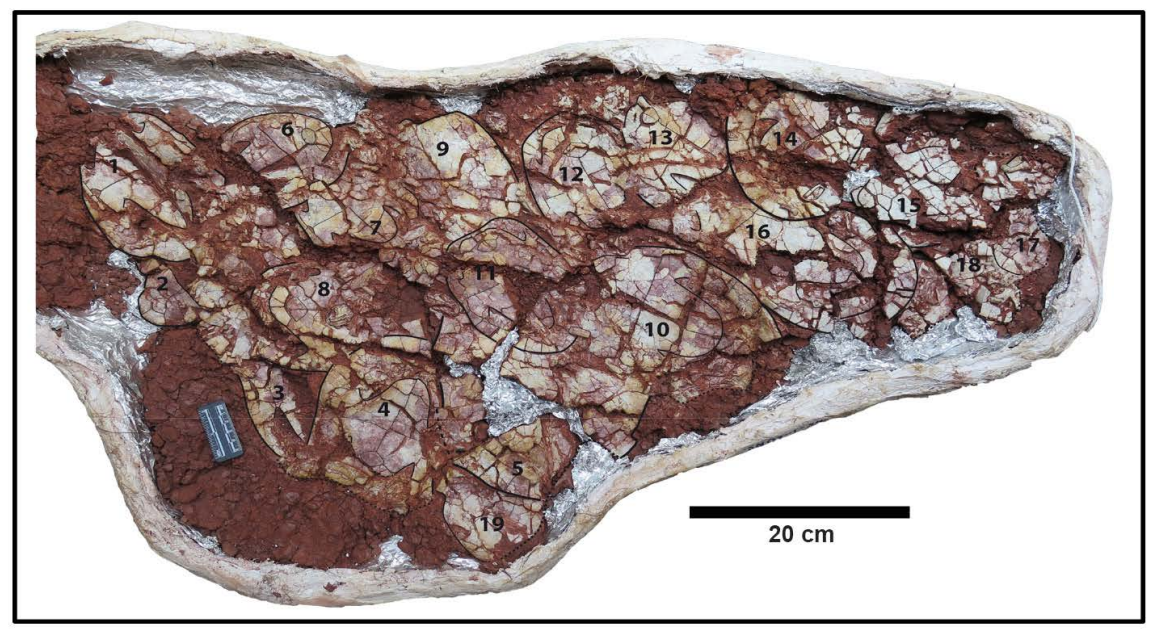

Figure 3. Nineteen adocid turtles accumulated together in reddish silty mudstone.

species lack of common specimens. Thus, this new Phu Sung goniopholidid can clarify the diversity of the Early Cretaceous crocodilian in Thailand. Moreover, few meters from where the crocodile remains were found, well preserved accumulated 19 turtle shells were discovered (Figure 3). These turtles belong to an adocid and are comparable to Isanemys srisuki. However, the turtles are still in the plaster jacket and need more preparation in another side for more information.

Although, the fossil assemblage from Phu Sung is quite similar to several sites from the Sao Khua Formation, the fossils from Phu Sung site such as crocodile and turtles are very complete with the exceptional preservation. These discoveries will certainly fulfill our knowledge about these aquatic taxa from the Lower Cretaceous Sao Khua Formation. The taphonomy and the extraordinary preservation of Phu Sung fossils could probably relate to the paleoenvironment and the 
paleoclimate changes in the Early Creataceous of Thailand. The further excavations and geological studies will help us to better understand the geology and paleontology of this site.

\section{Acknowledgements}

We are grateful to Mr. Woravit Tongsiri who informed us about this new site and all the support from the staffs of the National Reserved Forest of Phu Lom Khao and Phu Peg. We thank all the colleagues who took part in this work and strong support from the Department of Mineral Resources, Thailand. This is a contribution to UNESCO/IUGS/IGCP 679.

\section{Conflicts of Interest}

The authors declare no conflicts of interest regarding the publication of this paper.

\section{References}

[1] Tong, H., Buffetaut, E., Suteethorn, V., Suteethorn, S., Cuny, G., Cavin, L., Deesri, U., Martin, J.E., Wongko, K., Naksri, W. and Claude, J. (2019) Phu Din Daeng, a New Early Cretaceous Vertebrate Locality on the Khorat Plateau, NE Thailand. Annales de Paléontologie. https://doi.org/10.1016/j.annpal.2019.04.004

[2] Racey, A. and Goodall, J.G. (2009) Palynology and Stratigraphy of the Mesozoic Khorat Group Red Bed Sequences from Thailand. Geological Society, London, Special Publications, 315, 69-83. https://doi.org/10.1144/SP315.6

[3] Lauprasert, K., Cuny, G., Buffetaut, E., Suteethorn, V. and Thirakhupt, K. (2007) Siamosuchus phuphokensis, a New Goniopholidid from the Early Cretaceous (Ante-Aptian) of Northeastern Thailand. Bulletin de la Société Géologique de France, 178, 201-216. https://doi.org/10.2113/gssgfbull.178.3.201

[4] Buffetaut, E. and Ingavat, R. (1983) Goniopholis phuwiangensis nov. sp., a New Mesosuchian Crocodilian from the Mesozoic of Northeastern Thailiand. Géobios, 16, 79-91. https://doi.org/10.1016/S0016-6995(83)80048-5 